\title{
Outcome after Follow-Up Form Completion
}

National Cancer Institute

\section{Source}

National Cancer Institute. Outcome after Follow-Up Form Completion. NCI Thesaurus.

Code C156847.

The individual's outcome after the follow-up. 